\title{
KCNJ5 Mutations: Sex, Salt and Selection
}

\author{
Authors \\ T. A. Williams ${ }^{1,2}$, J. W. M. Lenders ${ }^{3,4}$, J. Burrello', F. Beuschlein ${ }^{2}$, M. Reincke ${ }^{2}$ \\ Affiliations \\ Division of Internal Medicine and Hypertension, Department of Medical Sciences, University of Turin, Turin, Italy \\ Medizinische Klinik und Poliklinik IV, Klinikum der Ludwig-Maximilians-Universität München, Munich, Germany \\ Department of Internal Medicine, Radboud University Medical Center, Nijmegen, The Netherlands \\ Department of Internal Medicine III, Technische Universität Dresden, Dresden, Germany
}

\author{
Key words \\ $\checkmark$ aldosterone-producing \\ adenoma \\ primary aldosteronism \\ - KCNJ5 \\ potassium channel
}

received 19.08.2015

accepted 07.10.2015

Bibliography

DOI http://dx.doi.org/

10.1055/s-0035-1565090

Published online:

November 13, 2015

Horm Metab Res 2015;

47: 953-958

(c) Georg Thieme Verlag KG

Stuttgart · New York

ISSN 0018-5043

\section{Correspondence}

\section{T. A. Williams}

Division of Internal Medicine

and Hypertension

Department of Medical

Sciences

University of Turin

Turin

Italy

Tel.: + 39/011/6336920

Fax: + 39/011/6336931

tracyannwilliams48@gmail.com

\section{Abstract \\ $\nabla$}

Somatic mutations have been identified in the KCNJ5 gene (encoding the potassium channel GIRK4) in aldosterone-producing adenomas (APA). Most of these mutations are located in or near the selectivity filter of the GIRK4 channel pore and

\section{Introduction}

The original description of somatic aldosteroneproducing adenoma (APA) mutations in the KCNJ5 gene by Choi et al. in 2011 [1] marks one of the defining moments in primary aldosteronism (PA) research that initiated an extraordinary avalanche of studies in this field. Within 2 years of the discovery of KCNJ5 mutations in APAs, the application of next-generation sequencing methods led to the identification of somatic APA mutations in 3 other genes. The affected genes were ATP1A1 and ATP2B3, encoding $\mathrm{Na}^{+} / \mathrm{K}^{+}$-ATPase 1 and $\mathrm{Ca}^{2+}$-ATPase 3 , respectively, and CACNA1D that encodes a subunit of an L-type voltage gated calcium channel, Cav1.3 [2-4]. However, in an intriguing development reported at the symposium Progress in Primary Aldosteronism 4 held in June 2015 and published recently [5], somatic mutations in ATP1A1, ATP2B3 and CACNA1D have also been identified in aldosterone-producing cell clusters (APCCs) in normal adrenal glands that stimulate CYP11B2 activity and aldosterone production. In a large European collaboration, Fernandes-Rosa et al. [6] reported the combined prevalence of somatic mutations in APAs in KCNJ5, ATP1A1, ATP2B3 and CACNA1D as 54\% ( $\odot$ Fig. 1). The functional effect of the thus far described somatic APA mutations all converge at the same intracellular level of the $\mathrm{Ca}^{2+}$ signalling pathway that ultimately lead to an increase in aldosterone biosynthesis [7-10]. The original identification of the somatic APA mutations in several have been shown to lead to the constitutive overproduction of aldosterone. KCNJ5 mutations in APA are more frequent in women; however, this gender dimorphism is a reported phenomenon of Western but not East Asian populations. In this review we discuss some of the issues that could potentially underlie this observation.

KCNJ5 [1] and the combined efforts of several other groups highlighting the role of these mutations in unilateral PA in driving aldosterone excess is surely one of the major advances in hypertension research over the last decade.

\section{G Protein-Activated Inwardly-Rectifying Potassium Channels \\ $\nabla$}

GIRK4 (encoded by KCNJ5, cytogenetic location: $11 q 24.3$ ) is a member of the family of G proteinactivated inwardly-rectifying potassium channels and is expressed at the plasma membrane in various different tissues, including the heart, central and peripheral neurons, various endocrine tissues, as well as in non-excitable structures [11]. GIRK channels form transmembrane permeation pathways or pores with a high selectivity for $\mathrm{K}^{+}$thereby preferentially allowing $\mathrm{K}^{+}$to flow into the cell. However, the directional flow of $\mathrm{K}^{+}$depends on where the ion channel is expressed. In adrenal zona glomerulosa cells, GIRK channels participate in maintaining the hyperpolarised state of the cell along with other $\mathrm{K}^{+}$channels by allowing an outward flow of $\mathrm{K}^{+}$ conductance [12]. The $\mathrm{K}^{+}$ion gradient across the cell membrane in GIRK channels is modulated in a voltage-dependent manner by the occlusion of the channel pore by intracellular polyamines and $\mathrm{Mg}^{2+}$ [13]. A GIRK channel subunit consists of 2 transmembrane helices with a large cytoplasmic domain and the $\mathrm{N}$ and $\mathrm{C}$ termini extruding into 


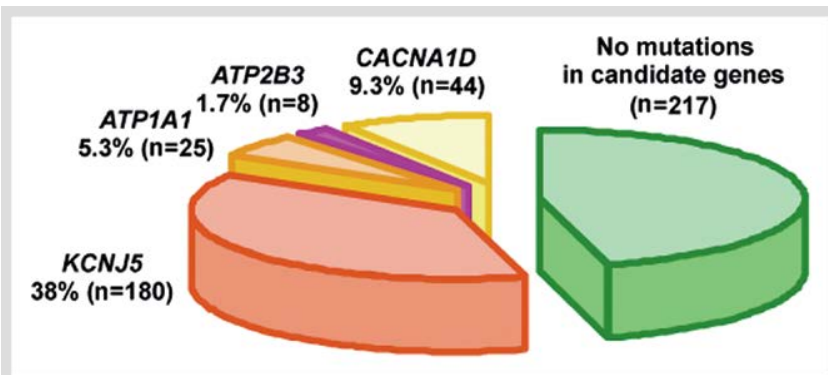

Fig. 1 Prevalence of somatic mutations in APA reported in a European cohort: The prevalence of somatic APA mutations in KCNJ5, ATP1A1, ATP2B3 and CACNA1D reported in a European cohort of APA $(n=474)$ recruited through the ENS@T registry (European Network for Adrenal Tumors, http://www.ensat.org/) [6].

the cytosol. An extracellular loop forms the selectivity filter that comprises the highly conserved signature sequence Gly-Tyr-Gly of $\mathrm{K}^{+}$channels. Functional GIRK channels are composed of 4 homo- or heterotetrameric subunits. Although GIRK4 can be expressed as a homotetramer, in most tissues and cell types it is found as a heterotetrameric complex with GIRK1, GIRK2 or GIRK3 [12].

The activation of GIRK channels is via direct interaction of the cytoplasmic domains with the $G$ protein $\beta$ r subunit and this process may also involve the anionic lipid phosphatidylinositol 4,5-bisphosphate [14]. In contrast, the inactivation of GIRK4 appears to be mediated by phospholipase $C$ activation [15]. The crystal structure of GIRK4 has not been resolved, however, that of the related channel GIRK2 in the closed as well as a constitutively active conformation has been determined both in the absence and presence of phosphatidylinositol 4,5-bisphosphate providing insights into the molecular mechanisms of the multiligand regulation of GIRK channels [16].

\section{Somatic KCNJ5 Mutations in APA \\ $\nabla$}

Choi et al. [1] identified GIRK4-p.Gly151Arg and p.Leu168Arg substitutions in 8 out of 22 APAs. Both of these mutations interfere with the selectivity filter of the ion channel and lead to the indiscriminate conductance of $\mathrm{Na}^{+}$through the pore of the outer tunnel ( $\bullet$ Fig. 2). The resultant membrane depolarisation causes the opening of $\mathrm{Ca}^{2+}$ voltage-gated ion channels, $\mathrm{Ca}^{2+}$ influx, activation of CYP11B2 transcription and increased aldosterone biosynthesis. The ensuing renewed interest in PA research led to the rapid determination of the prevalence of somatic KCNJ5 mutations in several cohorts of APAs [6,17-29]. Foremost was the study by Boulkroun et al. [17] ( $\odot$ Table 1 ) that additionally reported the predominance of APA-KCNJ5 mutations in women, an observation that was subsequently corroborated by others (๑ Table 1). Several novel mutations in KCNJ5 associated with APAs were also identified ( $\odot$ Fig. 3 ), however, the mutations that were first described are by far the most prevalent [1]. A recent meta-analysis that incorporated 13 studies involving 1636 patients showed that female gender is a phenotype of APA patients carrying KCNJ5 mutations along with pronounced aldosteronism, larger tumour size and younger age [30].

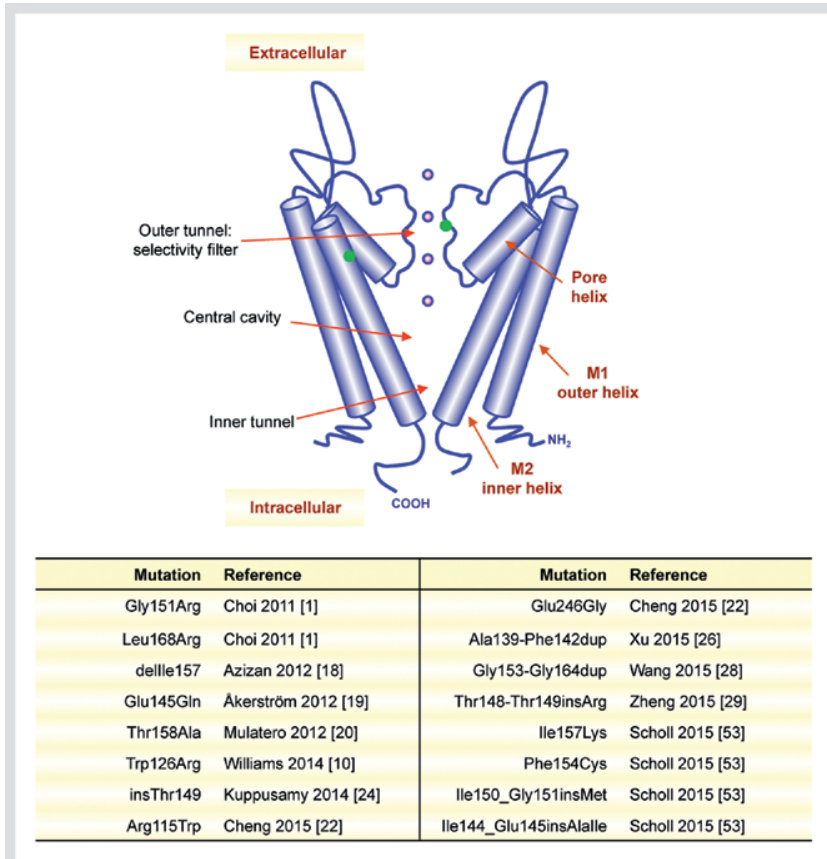

Fig. 2 Cartoon of the pore module of GIRK4: The cartoon represents the pore module of a $\mathrm{G}$ protein inwardly rectifying $\mathrm{K}^{+}$channel. The first transmembrane segment M1 faces the lipid bilayer and the second transmembrane segment forms the inner pore helix. The $\mathrm{K}^{+}$permeation pathway comprises the narrow outer tunnel with the ion selectivity filter, the central cavity and the inner tunnel. Functional GIRK channels are composed of 4 homo- or heterotetrameric subunits and GIRK 4 exists both as a homotetramer but more usually as a heterotetramer. The approximate positions of p.Gly151Arg in the selectivity filter of the outer tunnel and p.Leu168Arg in the inner helix are shown as green spheres. The somatic mutations identified to date with the reference that first reported them are shown in the panel below the figure. The figure was modified from a schematic diagram of the pore module of the Streptomyces lividans $\mathrm{K}^{+}$ channel [54] according to the corresponding structure of the chicken KCNJ12 channel [1], that shares $89 \%$ identity with human GIRK4 within the pore region and selectivity filter.

\section{Reported Prevalence of KCNJ5 Mutations in APA Patients in Different Populations $\nabla$}

Unilateral PA patients from Western populations report a lower prevalence of somatic APA KCNJ5 mutations compared to East Asian populations ( $\odot$ Table 1, 2, $\odot$ Fig. 3, 39 vs. 73\%, p<0.0001). Bilateral adrenal hyperplasia (BAH or idiopathic aldosteronism) is generally reported to account for around 2-thirds of all cases of PA [31]. In contrast, a Japanese nationwide epidemiological study reported that the frequency of unilateral APA predominated over BAH accounting for $86 \%$ of cases of APA and $14 \% \mathrm{BAH}$ patients $(n=1409)$ [32]. It is likely that this indicates a selection bias for APA patients that display a more pronounced phenotype with higher blood pressure levels compared to BAH patients; in fact, in the study by Miyake et al. [32], the unilateral APA patients displayed higher blood pressure levels compared to the BAH patients. Further, in China, where accessibility to AVS centres is limited, a selection bias is likely to exist and favour patients with a more florid phenotype potentially meaning those with large adrenal nodules. Other factors influencing the selection bias for APA in Japanese patients could be the use of ACTH stimulation during adrenal venous sampling (AVS) for subtype diagnosis in all Japanese centres: this could theoretically increase the aldos- 
Table 2 Reported prevalence of $K C N J 5$ mutations according to gender in East Asian populations.

\begin{tabular}{|c|c|c|c|}
\hline Population & Sample size & $\begin{array}{l}\text { KCNJ5 mutations } \\
\text { associated with } \\
\text { unilateral PA }\end{array}$ & Reference \\
\hline Japan & 5 & $5(100 \%)$ & Monticone 2012 [9] \\
\hline Men-No. (\%) & $2 / 5(40 \%)$ & $2 / 5(100 \%)$ & \\
\hline Women-No. (\%) & $3 / 5(60 \%)$ & $3 / 5(100 \%)$ & \\
\hline Japan & 23 & $15 / 23(65 \%)$ & Taguchi 2012 [25] \\
\hline Men-No. (\%) & $10 / 23(43 \%)$ & $7 / 10(70 \%)$ & \\
\hline Women-No. (\%) & $13 / 23(57 \%)$ & $8 / 13(62 \%)$ & \\
\hline Japan & $108^{*}$ & $75 / 108(69 \%)$ & Kitamoto 2015 [27] \\
\hline Men-No. (\%) & $37 / 103(36 \%)$ & $25 / 37(68 \%)$ & \\
\hline Women-No. (\%) & 66/103 (64\%) & $50 / 66$ (76\%) & \\
\hline China & 114 & $86 / 114(75 \%)$ & Wang 2015 [28] \\
\hline Men-No. (\%) & $52 / 114(46 \%)$ & $40 / 52(77 \%)$ & \\
\hline Women-No. (\%) & $62 / 114(54 \%)$ & $46 / 62(74 \%)$ & \\
\hline China & 168 & $129 / 168$ (77\%) & Zheng 2015 [29] \\
\hline Men-No. (\%) & $83 / 168$ (49\%) & $56 / 83(67 \%)$ & \\
\hline Women-No. (\%) & $85 / 168$ (51\%) & $73 / 85(86 \%)$ & \\
\hline
\end{tabular}

Table 3 Daily urinary $\mathrm{Na}^{+}$excretion in all participants from the INTERMAP population study reporting non-reduced salt and reduced salt diets.

\begin{tabular}{lll} 
Nation & Non-RSD & RSD \\
UK & $144.7 \pm 2.0(n=447)$ & $155.2 \pm 9.0(n=24)$ \\
USA & $163.6 \pm 1.2(n=2036)$ & $148.9 \pm 4.2(n=159)$ \\
\hline Japan & $198.9 \pm 1.5(n=1109)$ & $181.0 \pm 8.4(n=36)$ \\
China & $228.3 \pm 2.6(n=828)$ & $171.5 \pm 22.5(n=22.5)$
\end{tabular}

Data were from the study by Okuda et al. [36]. Numbers refer to the 24-h urinary $\mathrm{Na}^{+}$excretion in mmol (mean \pm standard error). In parenthesis, $\mathrm{n}=$ number of participants. RSD: reduced salt diet; non-RSD, Non-reduced salt diet

According to the China national diabetes and metabolic disorders study, $26.6 \%$ of Chinese adults (20 years or older, approximately 254 million individuals), are hypertensive [40]. If dietary salt intake is correlated to a more severe phenotype and/or earlier detection of the disease in APA patients [30] then it is likely to have a more pronounced effect in East Asian patients. Finally, another factor that could influence the detection of PA and some of its subtypes in different populations, is the difference in blood pressure sensitivity to aldosterone among races [41] that could potentially affect phenotype, detection and referral in different ethnic groups. However, the relevance of this in East Asians compared to other ethnic groups is unknown.

\section{Increased Prevalence of KCNJ5 Mutations in APA in Western Women \\ $\nabla$}

KCNJ5 mutations in APA have consistently been reported as more frequent in women in Western populations ( $\bullet$ Table 1, - Fig. 3). Table 1 shows the prevalence of KCNJ5 mutations in APA patients according to gender in cohorts from Europe, Australia and the USA (Western populations, $\odot$ Table 1, $\odot$ Fig. 3) with an overall predominance in women compared to men (55 vs. $22 \%, \mathrm{p}<0.0001$ ), in agreement with a recent meta-analysis [30]. In contrast, this distinction was not evident in East Asia (China and Japan, $\bigcirc$ Table 2) where there was no significant difference between genders (women vs. men: 79 vs. $71 \%$, ๑ Fig. 3).
In a European population, in addition to being more prevalent in women, KCNJ5 mutation status in APA patients was correlated with a younger age at diagnosis $[6,17]$. It is tempting to speculate that the younger age at diagnosis may have been a gender effect, potentially related to the reluctance of men to seek medical help and failing to do so until the disease has progressed [42]. Consistent with this idea is a Danish study that demonstrated a lower contact rate of men with the general practitioner, and higher rates of hospitalisation and mortality [43]. It would be relevant to study this hypothesis by analysing the severity of hypertension, and associated target organ damage at study entry according to gender and genotype. Interestingly, in a study to assess trends in hypertension in US adults (NHANES 1988-1994 and 1999-2004), among the race/ethnic groups studied, women generally showed better awareness, treatment, and control rates than men [44].

The interrelation of blood pressure and sex steroids may also play a role in the gender dimorphism of KCNJ5 mutation status in APA patients. Blood pressure levels are consistently reported to be higher in males compared to females [44-47]. This gender difference in blood pressure appears during adolescence and the relative prevalence of hypertension shifts to predominate in females in the elderly [48]. Interestingly, during the menopause transition, estradiol levels are $20 \%$ lower for Chinese and Japanese women compared to Caucasian, Hispanic or African-American women [49]. Estrogens are associated with protective cardiovascular effects [50] and 17 $\beta$-estradiol inhibits aldosterone synthesis in vitro via the estrogen $\beta$ receptor [51]. The role of dietary $\mathrm{Na}^{+}$excess in the pathogenesis of primary hypertension may have a more pronounced effect in men than in women [52]. Further, in a global survey, mean dietary $\mathrm{Na}^{+}$intake in men was around $10 \%$ higher than in women [39].

Therefore, pre-menopausal Western women with PA may not be exposed to the deleterious effects of higher blood pressure and higher salt intake to the extent of their male counterparts. Further, they might benefit from the protective vascular effects of estrogen. It is attractive to hypothesise that these factors may contribute to shift the balance towards KCNJ5 mutated APAs which are associated with a more severe phenotype and a higher likelihood of coming to medical attention.

\section{Summary and Conclusions}

$\nabla$

Patients with APA harbouring KCNJ5 mutations display a more severe form of aldosteronism and this may cause a selection bias in East Asian populations theoretically further exacerbated in Japanese centres by the use of ACTH stimulation during AVS.

Against a background of lower blood pressure levels, lower salt intake and vascular protection by estrogens, pre-menopausal female APA patients from Western populations may present for medical examination with a more pronounced aldosteronism compared to their male counterparts. This could potentially contribute to the sexual dimorphism of APA-KCNJ5 mutations in Western populations. In contrast, East Asian women have a higher dietary salt intake, higher blood pressure levels and lower estrogen levels than Western women.

To address any potential pathophysiological basis of these issues: 1) cohorts of APA-KCNJ5 patients could be analysed according to clinical phenotype (blood pressure, biochemical and hormonal parameters) and gender; 2 ) the true prevalence of KCNJ5 mutations could be analysed in a large (unbiased) autopsy study from 
both Western and Asian populations within the same age range as the published cohort series; and 3) the mutational status of APA patients could be correlated with parameters of quality of life and psychological well-being in a multivariate adjusted analysis to study gender-dependent effects on hypertension presentation.

\section{Acknowledgements}

$\nabla$

This work was funded by a grant from the Deutsche Forschungsgemeinschaft (RE 752/20-1 to M.R. and BE 2177/13-1 to F.B.) and by a grant of the Else Kröner-Fresenius Stiftung (2013_A182) to M.R.

\section{Conflict of Interest}

$\nabla$

The authors declare no conflict of interest.

\section{References}

1 Choi M, Scholl UI, Yue P, Björklund P, Zhao B, Nelson-Williams C, Ji W, Cho Y, Patel A, Men CJ, Lolis E, Wisgerhof MV, Geller DS, Mane S, Hellman P, Westin G, Åkerström G, Wang W, Carling T, Lifton RP. K+ channel mutations in adrenal aldosterone-producing adenomas and hereditary hypertension. Science 2011; 331: 768-772

2 Beuschlein $F$, Boulkroun $S$, Osswald A, Wieland T, Nielsen HN, Lichtenauer UD, Penton D, Schack VR, Amar L, Fischer E, Walther A, Tauber P, Schwarzmayr T, Diener S, Graf E, Allolio B, Samson-Couterie $B$, Benecke A, Quinkler M, Fallo F, Plouin PF, Mantero F, Meitinger T, Mulatero P, Jeunemaitre X, Warth R, Vilsen B, Zennaro MC, Strom TM, Reincke M. Somatic mutations in ATP1A1 and ATP2B3 lead to aldosterone-producing adenomas and secondary hypertension. Nat Genet 2013; 45: 440-444

3 Azizan EA, Poulsen H, Tuluc P, Zhou J, Clausen MV, Lieb A, Maniero C, Garg S, Bochukova EG, Zhao W, Shaikh LH, Brighton CA, Teo AE, Davenport AP, Dekkers T, Tops B, Kusters B, Ceral J, Yeo GS, Neogi SG, McFarlane I, Rosenfeld N, Marass F, Hadfield J, Margas W, Chaggar K, Solar M, Deinum J, Dolphin AC, Farooqi IS, Striessnig J, Nissen P, Brown MJ. Somatic mutations in ATP1A1 and CACNA1D underlie a common subtype of adrenal hypertension. Nat Genet 2013; 45: 1055-1060

4 Scholl UI, Goh G, Stolting G, de Oliveira RC, Choi M, Overton JD, Fonseca $A L$, Korah R, Starker LF, Kunstman JW, Prasad ML, Hartung EA, Mauras $N$, Benson MR, Brady T, Shapiro JR, Loring E, Nelson-Williams C, Libutti SK, Mane S, Hellman P, Westin G, Åkerström G, Björklund P, Carling T, Fahlke $C$, Hidalgo $P$, Lifton RP. Somatic and germline CACNA1D calcium channel mutations in aldosterone-producing adenomas and primary aldosteronism. Nat Genet 2013; 45: 1050-1054

5 Nishimoto K, Tomlins SA, Kuick R, Cani AK, Giordano TJ, Hovelson DH, Liu CJ, Sanjanwala AR, Edwards MA, Gomez-Sanchez CE, Nanba $K$, Rainey WE. Aldosterone-stimulating somatic gene mutations are common in normal adrenal glands. Proc Natl Acad Sci USA 2015; 112: E4591-E4599

6 Fernandes-Rosa FL, Williams TA, Riester A, Steichen O, Beuschlein F, Boulkroun S, Strom TM, Monticone S, Amar L, Meatchi T, Mantero F, Cicala MV, Quinkler M, Fallo F, Allolio B, Bernini G, Maccario M, Giacchetti G, Jeunemaitre X, Mulatero P, Reincke M, Zennaro MC. Genetic spectrum and clinical correlates of somatic mutations in aldosteroneproducing adenoma. Hypertension 2014; 64: 354-361

7 Oki K, Plonczynski MW, Luis Lam M, Gomez-Sanchez EP, Gomez-Sanchez CE. Potassium channel mutant KCNJ5 T158A expression in HAC-15 cells increases aldosterone synthesis. Endocrinology 2012; 153: 1774-1782 8 Williams TA, Monticone S, Crudo V, Warth R, Veglio F, Mulatero P. Visinin-like 1 is upregulated in aldosterone-producing adenomas with KCNJ5 mutations and protects from calcium-induced apoptosis. Hypertension 2012; 59: 833-839

9 Monticone S, Hattangady NG, Nishimoto K, Mantero F, Rubin B, Cicala MV, Pezzani R, Auchus RJ, Ghayee HK, Shibata H, Kurihara I, Williams TA, Giri JG, Bollag RJ, Edwards MA, Isales CM, Rainey WE. Effect of KCNJ5 mutations on gene expression in aldosterone-producing adenomas and adrenocortical cells. J Clin Endocrinol Metab 2012; 97: E1567-E1572
10 Williams TA, Monticone S, Schack VR, Stindl J, Burrello J, Buffolo F, Annaratone L, Castellano I, Beuschlein F, Reincke M, Lucatello B, Ronconi V, Fallo F, Bernini G, Maccario M, Giacchetti G, Veglio F, Warth $R$, Vilsen B, Mulatero P. Somatic ATP1A1, ATP2B3, and KCNJ5 mutations in aldosterone-producing adenomas. Hypertension 2014; 63: 188-195

11 Mulatero P, Monticone S, Rainey WE, Veglio F, Williams TA. Role of KCNJ5 in familial and sporadic primary aldosteronism. Nat Rev Endocrinol 2013; 9: 104-112

12 Gomez-Sanchez CE, Oki K. Minireview: potassium channels and aldosterone dysregulation: is primary aldosteronism a potassium channelopathy? Endocrinology 2014; 155: 47-55

13 Hibino H, Inanobe A, Furutani K, Murakami S, Findlay I, Kurachi Y. Inwardly rectifying potassium channels: their structure, function, and physiological roles. Physiol Rev 2010; 90: 291-366

14 Sadja $R$, Smadja K, Alagem N, Reuveny E. Coupling Gbetagammadependent activation to channel opening via pore elements in inwardly rectifying potassium channels. Neuron 2001; 29: 669-680

15 Mao J, Wang X, Chen F, Wang R, Rojas A, Shi Y, Piao H, Jiang C. Molecular basis for the inhibition of $G$ protein-coupled inward rectifier $\mathrm{K}(+)$ channels by protein kinase C. Congest Heart Fail 2006; 12: 200-205

16 Whorton MR, MacKinnon R. Crystal structure of the mammalian GIRK2 $\mathrm{K}+$ channel and gating regulation by $\mathrm{G}$ proteins, PIP2, and sodium. Cell 2011; 147: 199-208

17 Boulkroun S, Beuschlein F, Rossi GP, Golib-Dzib JF, Fischer E, Amar L, Mulatero P, Samson-Couterie B, Hahner S, Quinkler M, Fallo F, Letizia C, Allolio B, Ceolotto G, Cicala MV, Lang K, Lefebvre H, Lenzini L, Maniero $C$, Monticone S, Perrocheau M, Pilon C, Plouin PF, Rayes N, Seccia TM, Veglio F, Williams TA, Zinnamosca L, Mantero F, Benecke A, Jeunemaitre $X$, Reincke M, Zennaro MC. Prevalence, clinical, and molecular correlates of KCNJ5 mutations in primary aldosteronism. Hypertension 2012; 59: 592-598

18 Azizan EA, Murthy M, Stowasser M, Gordon R, Kowalski B, Xu S, Brown $M J$, O'Shaughnessy KM. Somatic mutations affecting the selectivity filter of KCNJ5 are frequent in 2 large unselected collections of adrenal aldosteronomas. Hypertension 2012; 59: 587-591

19 Åkerström T, Crona J, Delgado Verdugo A, Starker LF, Cupisti K, Willenberg HS, Knoefel WT, Saeger W, Feller A, Ip J, Soon P, Anlauf M, Alesina $P F$, Schmid KW, Decaussin M, Levillain P, Wängberg B, Peix JL, Robinson $B$, Zedenius J, Bäckdahl M, Caramuta S, Iwen KA, Botling J, Stålberg $P$, Kraimps JL, Dralle H, Hellman P, Sidhu S, Westin G, Lehnert H, Walz MK, Åkerström G, Carling T, Choi M, Lifton RP, Björklund P. Comprehensive re-sequencing of adrenal aldosterone producing lesions reveal three somatic mutations near the KCNJ5 potassium channel selectivity filter. PLoS One 2012; 7: e41926

20 Mulatero P, Tauber P, Zennaro MC, Monticone S, Lang K, Beuschlein F Fischer E, Tizzani D, Pallauf A, Viola A, Amar L, Williams TA, Strom TM, Graf E, Bandulik S, Penton D, Plouin PF, Warth R, Allolio B, Jeunemaitre $X$, Veglio F, Reincke $M$. KCNJ5 mutations in European families with nonglucocorticoid remediable familial hyperaldosteronism. Hypertension 2012; 59: 235-240

21 Arnesen T, Glomnes N, Strømsøy S, Knappskog S, Heie A, Akslen LA Grytaas M, Varhaug JE, Gimm O, Brauckhoff M. Outcome after surgery for primary hyperaldosteronism may depend on KCNJ5 tumor mutation status: a population-based study from Western Norway. Langenbecks Arch Surg 2013; 398: 869-874

22 Cheng CJ, Sung CC, Wu ST, Lin YC, Sytwu HK, Huang CL, Lin SH. Novel KCNJ5 mutations in sporadic aldosterone-producing adenoma reduce Kir3.4 membrane abundance. J Clin Endocrinol Metab 2015; 100: E155-E163

23 Dekkers T, ter Meer M, Lenders JW, Hermus AR, Schultze Kool L, Langenhuijsen JF, Nishimoto K, Ogishima T, Mukai K, Azizan EA, Tops B, Deinum J, Küsters B. Adrenal nodularity and somatic mutations in primary aldosteronism: one node is the culprit? J Clin Endocrinol Metab 2014; 99: E1341-E1351

24 Kuppusamy M, Caroccia B, Stindl J, Bandulik S, Lenzini L, Gioco F, Fishman V, Zanotti G, Gomez-Sanchez C, Bader M, Warth R, Rossi GP. A novel KCNJ5-insT149 somatic mutation close to, but outside, the selectivity filter causes resistant hypertension by loss of selectivity for potassium. J Clin Endocrinol Metab 2014; 99: E1765-E1773

25 Taguchi $R$, Yamada M, Nakajima Y, Satoh T, Hashimoto K, Shibusawa $N$, Ozawa A, Okada S, Rokutanda N, Takata D, Koibuchi Y, Horiguchi J, Oyama T, Takeyoshi I, Mori M. Expression and mutations of KCNJ5 mRNA in Japanese patients with aldosterone-producing adenomas. J Clin Endocrinol Metab 2012; 97: 1311-1319

26 Xu S, Hardege I, Murthy M, Gordon R, Stowasser M, O'Shaughnessy K. A novel insertional somatic KCNJ5 mutation in an Australian patient with an aldosterone producing adenoma. J Hypertens 2015; 33: e120 
27 Kitamoto T, Suematsu S, Matsuzawa Y, Saito J, Omura M, Nishikawa T. Comparison of cardiovascular complications in patients with and without KCNJ5 gene mutations harboring aldosterone-producing adenomas. J Atheroscler Thromb 2015; 22: 191-200

28 Wang $B$, Li X, Zhang X, Ma X, Chen L, Zhang Y, Lyu X, Tang Y, Huang $Q$, Gao Y, Fan Y, Ouyang J. Prevalence and characterization of somatic mutations in Chinese aldosterone-producing adenoma patients. Medicine 2015; 94: e708

29 Zheng FF, Zhu LM, Nie AF, Li XY, Lin JR, Zhang K, Chen J, Zhou WL, Shen ZJ, Zhu YC, Wang JG, Zhu DL, Gao PJ. Clinical characteristics of somatic mutations in Chinese patients with aldosterone-producing adenoma. Hypertension 2015; 65: 622-628

30 Lenzini L, Rossitto G, Maiolino G, Letizia C, Funder JW, Rossi GP. A MetaAnalysis of Somatic KCNJ5 K+channel mutations in 1636 patients with an aldosterone-producing adenoma. J Clin Endocrinol Metab 2015; 100: E1089-E1095

31 Schirpenbach C, Reincke M. Primary aldosteronism: current knowledge and controversies in Conn's syndrome. Nat Clin Pract Endocrinol Metab 2007; 3: 220-227

32 Miyake Y, Tanaka K, Nishikawa T, Naruse M, Takayanagi R, Sasano $H$, Takeda Y, Shibata H, Sone M, Satoh F, Yamada M, Ueshiba H, Katabami T, Iwasaki Y, Tanaka H, Tanahashi Y, Suzuki S, Hasegawa T, Katsumata $N$, Tajima $T$, Yanase T. Prognosis of primary aldosteronism in Japan: results from a nationwide epidemiological study. Endocr J 2014; 61: $35-40$

33 Young WF, Stanson AW, Thompson GB, Grant CS, Farley DR, van Heerden JA. Role for adrenal venous sampling in primary aldosteronism. Surgery 2004; 136: 1227-1235

34 Azizan EA, Lam BY, Newhouse SJ, Zhou J, Kuc RE, Clarke J, Happerfield L, Marker A, Hoffman GJ, Brown MJ. Microarray, qPCR, and KCNJ5 sequencing of aldosterone-producing adenomas reveal differences in genotype and phenotype between zona glomerulosa- and zona fasciculata-like tumors. J Clin Endocrinol Metab 2012; 97: E819-E829

35 Monticone S, Castellano I, Versace K, Lucatello B, Veglio F, GomezSanchez CE, Williams TA, Mulatero P. Immunohistochemical, genetic and clinical characterization of sporadic aldosterone-producing adenomas. Mol Cell Endocrinol 2015; 411: 146-154

36 Okuda N, Stamler J, Brown IJ, Ueshima H, Miura K, Okayama A, Saitoh S, Nakagawa H, Sakata K, Yoshita K, Zhao L, Elliott P, INTERMAP Research Group. Individual efforts to reduce salt intake in China, Japan, UK, USA: what did people achieve? The INTERMAP Population Study. J Hypertens 2014; 32: 2385-2392

37 Intersalt: an international study of electrolyte excretion and blood pressure. Results for 24 hour urinary sodium and potassium excretion. Intersalt Cooperative Research Group. BMJ 988 297: 319-328

38 Stamler J, Rose G, Elliott P, Dyer A, Marmot M, Kesteloot H, Stamler R. Findings of the International Cooperative INTERSALT Study. Hypertension 1991; 17: 19-15

39 Powles J, Fahimi S, Micha R, Khatibzadeh S, Shi P, Ezzati M, Engell RE, Lim SS, Danaei G, Mozaffarian D, Global Burden of Diseases Nutrition and Chronic Diseases Expert Group (NutriCoDE). Global, regional and national sodium intakes in 1990 and 2010: a systematic analysis of $24 \mathrm{~h}$ urinary sodium excretion and dietary surveys worldwide. BMJ Open 2013; 3: e003733
40 Gao Y, Chen G, Tian H, Lin L, Lu J, Weng J, Jia W, Ji L, Xiao J, Zhou Z, Ran X, Ren $Y$, Chen $T$, Yang $W$, and for the China National Diabetes and Metabolic Disorders Study Group. Prevalence of Hypertension in China: A Cross-Sectional Study. PLoS One 2013; 8: e65938

41 Tu W, Eckert GJ, Hannon TS, Liu H, Pratt LM, Wagner MA, Dimeglio LA, Jung J, Pratt JH. Racial differences in sensitivity of blood pressure to aldosterone. Hypertension 2014; 63: 1212-1218

42 Banks I. No man's land: men, illness, and the NHS. BMJ 2001; 323 1058-1060

43 Juel K, Christensen K. Are men seeking medical advice too late? Contacts to general practitioners and hospital admissions in Denmark 2005. J Public Health 2008; 30: 111-113

44 Cutler JA, Sorlie PD, Wolz M, Thom T, Fields LE, Roccella EJ. Trends in hypertension prevalence, awareness, treatment, and control rates in United States adults between 1988-1994 and 1999-2004. Hypertension 2008; 52: 818-827

45 Os I, Oparil S, Gerdts E, Høieggen A. Essential hypertension in women. Blood Press 2004; 13: 272-278

46 Burt VL, Whelton P, Roccella EJ, Brown C, Cutler JA, Higgins M, Horan $M J$, Labarthe $D$. Prevalence of hypertension in the US adult population. Results from the Third National Health and Nutrition Examination Survey, 1988-1991. Hypertension 1995; 25: 305-313

47 Sandberg $\mathrm{K}, \mathrm{Ji} \mathrm{H}$. Sex differences in primary hypertension. Biol Sex Differ 2012; 3: 7

48 Kotchen JM, McKean HE, Kotchen TA. Blood pressure trends with aging. Hypertension 1982; 4: III128-III134

49 Baber RJ. East is east and West is west: perspectives on the menopause in Asia and The West. Climacteric 2014; 17: 23-28

50 Rossi P, Francès $Y$, Kingwell BA, Ahimastos AA. Gender differences in artery wall biomechanical properties throughout life. J Hypertens 2011; 29: 1023-1033

51 Caroccia B, Seccia TM, Campos AG, Gioco F, Kuppusamy M, Ceolotto G, Guerzoni E, Simonato F, Mareso S, Lenzini L, Fassina A, Rossi GP. GPER-1 and estrogen receptor- $\beta$ ligands modulate aldosterone synthesis. Endocrinology 2014; 155: 4296-4304

52 Hedayati SS, Minhajuddin AT, Ijaz A, Moe OW, Elsayed EF, Reilly RF, Huang $C L$. Association of urinary sodium/potassium ratio with blood pressure: sex and racial differences. Clin J Am Soc Nephrol 2012; 7: 315-322

53 Scholl UI, Healy JM, Thiel A, Fonseca AL, Brown TC, Kunstman JW, Horne MJ, Dietrich D, Riemer J, Kücükköylü S, Reimer EN, Reis AC, Goh G, Kristiansen G, Mahajan A, Korah R, Lifton RP, Prasad ML, Carling T. Novel somatic mutations in primary hyperaldosteronism are related to the clinical, radiological and pathological phenotype. Clin Endocrinol 2015, Aug 7 doi: doi: 10.1111/cen.12873 [Epub ahead of print]

54 Sepúlveda FV, Cid LP, Teulon J, Niemeyer MI. Molecular aspects of structure, gating, and physiology of pH-sensitive background K2P and Kir K+-transport channels. Physiol Rev 2015; 95: 179-217 